\title{
The Role of Time Exposed to Outdoor Light for Myopia Prevalence and Progression: A Literature Review
}

This article was published in the following Dove Press journal: Clinical Ophthalmology

\author{
Leila Sara Eppenberger' \\ Veit Sturm ${ }^{1,2}$ \\ 'Department of Health Sciences \& \\ Technology, ETH, Zurich, Switzerland; \\ ${ }^{2}$ Eye Department, Cantonal Hospital, \\ St. Gallen, Switzerland
}

Purpose: The development of myopia as a refractive disorder seems to hold multifactorial causes. Among others, increased time exposed to natural light outdoors is regarded as possible effective preventive measure against myopia development. The objective of this review is to analyse and summarize the evidence investigating the association between time outdoors and myopia prevalence and progression.

Methods: A review, restricted to articles published in the last ten years, was conducted. The literature search for the included articles was performed in the following databases: PubMed, the Cochrane Library, Web of Science and Scopus. If predefined inclusion criteria were met, the studies were further categorized and data were summarized and individually evaluated.

Results: Two cross-sectional studies, 7 prospective cohort studies and 3 intervention studies were reported in this review, representing the data of a total of 32,381 participants. The majority of the studies found an inverse association between myopia incidence/prevalence and increased time outdoors. The association between time outdoors and myopia progression on the other hand remains debatable; one recent randomized controlled trial indicating a protective value of increased time outdoors for further progression in myopic children.

Conclusion: In summary, increasing time exposed to outdoor light seems to be a simple and effective preventive measure to decrease myopia prevalence. Also, contrasting previous review work, it may represent a potential strategy for myopia progression control. Future investigation is necessary to better define and quantify outdoor time and its effects on myopia.

Keywords: myopia, prevalence, progression, exposure to sunlight, outdoor exposure, myopia control

\section{Introduction}

Myopia, also known as near-sightedness, is the most common refractive disorder of the eye globally. Due to a relatively long axial length of the eye, light rays focus in front of the retina, which in turn results in a blurred image. ${ }^{1}$ As the severity of its complications increases with increasing grade of myopia, a distinction is made between myopia and high myopia. The following represents the commonly used technical definition of myopia. ${ }^{2}$ A condition in which the spherical equivalent objective refractive error is $\leq-0.50$ diopter $(-0.50 \mathrm{D})$ in either eye is defined as myopia. High myopia comprises conditions in which the spherical equivalent objective refractive error is $\leq-5.00 \mathrm{D}$ in either eye.

Today, myopia affects around one-third of world population, with significant geographical differences. In $2010,4 \%$ of the global population was affected by high myopia. ${ }^{1}$ In some developed parts of East Asia the prevalence rates of myopia
Correspondence: Leila Sara Eppenberger Rorschacherstr. 95,St. Gallen 9007, Switzerland

Tel + 4I 792469703

Email leila.eppenberger@uzh.ch 
among young adults reach up to $80-90 \%$ and even $20 \%$ for high myopia. ${ }^{3}$ Data from Europe shows an estimated pooled prevalence of $27 \%(95 \% \mathrm{CI}=22.4-31.6) .{ }^{4}$ Rates from recent studies in North America have shown a prevalence of $41.9 \%$ in children, ${ }^{5}$ while studies in South America found it to be $11.6 \%{ }^{6}$ Studies suggest that the prevalence of myopia will increase even further and is predicted to double $(49.8 \%)$ by 2050 , potentially affecting more than 4.7 Billion worldwide. ${ }^{1}$

Altogether, the effect of myopia on eye health is comparable to the effect of hypertension on the cardiovascular system and is therefore in progress to become the number one reason for blindness. $1,7-9$

A variety of myopia forms exist and should be considered. There are some rare hereditary forms which are commonly found in the context of syndromes (eg, Marfan syndrome or congenital stationary night blindness). They run in families and are to be distinguished from the much more frequent form of non-syndromic myopia discussed in this review, which cannot be explained by a genetic cause alone, but refers to a form which is relevantly influenced by several already identified environmental factors instead. ${ }^{10,11}$ This type of myopia has contributed to the epidemic-like increase in prevalence of past decades. Recent studies have provided evidence for the existence of mechanisms in which eye growth depends on environmental factors; both excessive near-work and a lack of outdoor exposure, among other factors, have been taken into closer focus for their possible underlying roles. It seems that time outdoors protects children from becoming or being myopic. There is an increasing number of studies investigating the connection between outdoor time and myopia. ${ }^{12-19}$

As the increase of recent publications shows; there is a continuously growing interest in the topic of myopia, and demand for concrete mitigation strategies. For this reason, the objective of this review is to provide a critical analysis of the data investigating the association between time spent exposed to natural light (outdoor time) and myopia prevalence and progression. It considers publications of the past ten years and focuses - in comparison to the last review article by Xiong et $\mathrm{al}^{3}$ - on more recently published prospective cohort studies and randomized controlled studies.

\section{Methods}

\section{Search Strategy}

The main research question: "How is the association between time spent exposed to natural light (outdoor) and myopia prevalence and progression in children?" guided our search strategy. The literature search was initially performed in two databases, PubMed and the Cochrane Library. The terms "myopia" or "near-sightedness" were combined with "outdoor" or other similar search terms ("outside", "UV-light", "sunlight", "activity") as well as "progression" and "prevention”. Following a clear electronic search protocol databases were searched, see Supplementary Material. Articles published between October 2008 and January 2019 were considered. Then, the identified articles were saved in Zotero from which a biography list was generated and exported to Excel for further analysis and selection. ${ }^{20}$

Moreover, the references of retrieved publications were used and alerts for new publications were saved in PubMed to assure that no relevant new studies were missed between the main search point and the analysis of the literature.

Since all the included studies adhere to the guidelines of the Declaration of Helsinki and solely a literature analysis was conducted, an approval for the conduction of this review paper was not needed.

\section{Selection of the Studies}

After elimination of duplicates, the remaining abstracts of all the retrieved articles were summarized and the corresponding articles were grouped according to their study type. There were three groups: (1) intervention studies, (2) observational studies and (3) all other publications.

Inclusion criteria (Table 1) were defined for observational studies, ie, cross-sectional and cohort studies, and intervention studies. Other types of studies such as review publications and comments, as well as experimental studies with animals were treated separately. For cross-sectional studies the number of participants in the individual study needed to be 1000 or more, whereas cohort studies were included if their sample size was $n \geq 500$. Children and adolescents aged 6-18 years were included. Studies from the same study population or the same author underwent reselection to include only the newest or the one most accurately matching the main research question. Only papers in English or German language were selected. For inclusion, the association between outdoor time in relation to prevalence or progression of myopia had to be precisely described for instance by an effect estimate, an odds ratio with a $95 \%$ confidence interval or standard error. Lastly, the measurement procedure of myopia needed to be objective, thus studies in which myopia was determined by means of survey or indirectly assessed (eg, spectacle wearing) were excluded. 
Table I Inclusion Criteria for Articles to the Review

\begin{tabular}{|l|l|}
\hline Criterion & Inclusion \\
\hline $\begin{array}{l}\text { Research } \\
\text { question }\end{array}$ & $\begin{array}{l}\text { Clear statement about association between } \\
\text { "outdoor exposure" and "myopia prevalence / } \\
\text { progression" }\end{array}$ \\
\hline $\begin{array}{l}\text { Number ( } \mathrm{n} \text { ) of } \\
\text { participants }\end{array}$ & $\begin{array}{l}\text { For cross-sectional studies } \mathrm{n} \geq 1000 \\
\text { For cohort studies } \mathrm{n} \geq 500\end{array}$ \\
\hline participants & $6-18$ years \\
\hline Language & English or German \\
\hline $\begin{array}{l}\text { Same study } \\
\text { population }\end{array}$ & $\begin{array}{l}\text { Only one article: either the newest or the one } \\
\text { with the clearest statement about the main } \\
\text { research question }\end{array}$ \\
\hline $\begin{array}{l}\text { Myopia } \\
\text { measurement }\end{array}$ & $\begin{array}{l}\text { Objective measurement: refraction (ideally with } \\
\text { cycloplegia). axial length of the eye }\end{array}$ \\
\hline $\begin{array}{l}\text { Definition of } \\
\text { exposure }\end{array}$ & $\begin{array}{l}\text { Precise description of the exposure "outdoor } \\
\text { time" }\end{array}$ \\
\hline $\begin{array}{l}\text { Report of } \\
\text { association }\end{array}$ & $\begin{array}{l}\text { Effect estimate with 95\% confidence interval } \\
\text { (Cl) or standard error (SE) }\end{array}$ \\
\hline
\end{tabular}

\section{Quality of Studies and Data Extraction}

The PRISMA checklist guided the data extraction and quality assessment of the selected publications for this review. ${ }^{21}$ Study type, authors' names, year of publication, geographical region of origin, sample size, subjects' age, definition and measurement of myopia, method of assessment of outdoor time, respectively, activity, duration of follow-up in the case of intervention or prospective cohort studies, and outcomes with effect estimates and their 95\% confidence intervals or standard deviations were extracted from the selected publications.

The main variables for assessing the quality of the studies were (I) the process of selection of study participants, (II) measurement methods of exposure (outdoor time) and outcome (myopia), (III) description and number of possible biases and the (IV) effect estimate of the association. To highlight the novel findings of this review a comparison to the two previously performed systematic reviews ${ }^{3,18}$ on the association between time spent outdoors and myopia in children was conducted. The articles which were selected for this review were further labelled if they had already been part of one or both of the earlier reviews.

Articles related to the main research question, which did not meet all of the inclusion criteria or had another format were considered separately. Finally, retrieved comments or statements on some of the highly cited studies in this field of research were summarized and also included in this review.

\section{Results \\ Identification and Selection of Articles for the Review}

We identified a total of 167 publications, after the removal of duplicates 155 articles remained. Further 30 publications were excluded in a first round mainly because of a lack in relevance to the research question $(n=19)$. Figure 1 shows the selection process in a flow diagram. The remaining 125 publications were subdivided into three categories: interventional studies $(n=7)$, observational studies $(n=60)$ and the last category comprised reviews and comments on articles $(n=38)$, experimental studies $(n=5)$, as well as other related articles $(\mathrm{n}=15)$.

In the end, three controlled intervention studies, ${ }^{22-24}$ two cross-sectional studies ${ }^{25,26}$ and seven prospective cohort studies $^{27-33}$ met the inclusion criteria for this review (Table 1).

An exception to inclusion criteria concerning age range of participants (6 to 18 years) was made for the article by Dirani et al. ${ }^{25}$ Participants' mean age was 13.7 years but the age range was 11 to 20 years of age. The article was kept because it specifically addresses the association between outdoor time and myopia prevalence, it has been frequently cited and the mean age of participants still fell into the predefined criterion of age range.

\section{General Characteristics of the Included Articles}

To better visualize the articles' release date, a timeline was made (Figure 2); five of the seven prospective cohort studies were published after 2015 and three publications, one cross-sectional $^{25}$ and two prospective cohort studies ${ }^{28,30}$ were published between 2009 and 2015. Therefore, 11 of the 12 selected articles for this review were published after the review by Sherwin et al. ${ }^{18}$ In summary, the included articles represent the data of a total of 32,381 study participants. The two cross-sectional studies contain a total of 5002 participants, whereas the seven prospective cohort studies represent a total of 22,026 participants and the three controlled intervention trials cover 5353 participants.

With respect to geographical origin, most of the studies were conducted in Asian countries, which can be explained by the region's relatively greater extent of the myopia 


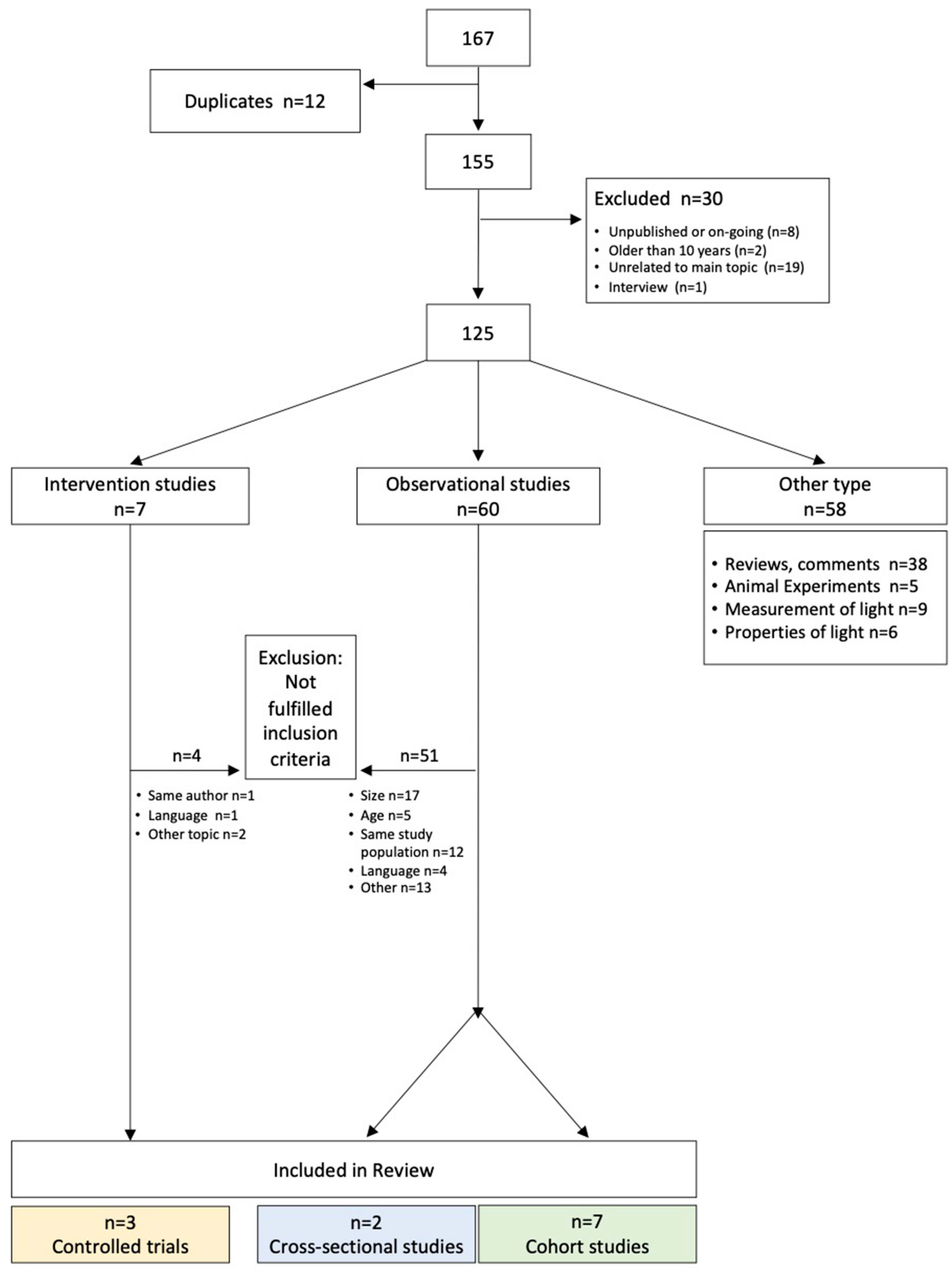

Figure I Flow diagram indicating the selection process for study inclusion.

problem. ${ }^{14}$ Figure 3 shows the geographical origin of the studies and the total number of participants from the different geographical areas. Forty-five percent of the study participants came from China and 30\% from India. Only ten percent represent both Europe (6\%) and the USA (3\%). When focusing on the interventional studies, two were 


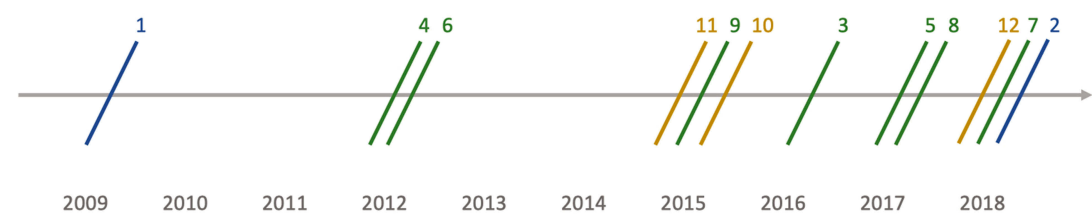

Figure 2 Publication time of included studies.

Notes: Cross-sectional studies are marked in blue, prospective cohort studies in green and intervention studies in yellow. The numbering corresponds to the sequence in Tables 2 and 3.

conducted in China: one in Guangzhou and one in Sujiatun. ${ }^{22,23}$ The third and most recent trial was carried out in Taiwan. ${ }^{24}$

A summary of the main characteristics of the selected articles is given in Table 2 .

\section{Quality of the Selected Articles Selection of Study Participants}

Participant selection largely depended on study type. The selection methods for cross-sectional studies and prospective cohort studies are reported first. In four studies pre-existing cohorts were analysed; Dirani et al investigated children of the Singapore Cohort Study of the Risk Factors for Myopia (SCORM). ${ }^{25}$ The other three were prospective cohort studies: Chen et $\mathrm{al}^{27}$ looked at all the first-born twins of the Guangzhou Twins Eye Study (GTES). Guggenheim et al analysed the data of children from the Avon longitudinal study of parents and children (ALSPAC) ${ }^{28}$ and Jones-Jordan used myopic children from the CLEERE (Collaborative Longitudinal Evaluation of Ethnicity and Refractive Error) cohort. ${ }^{30}$ A randomized selection of study participants took place in the large cross-sectional study by Sun et al, where 10 schools from Qingdao were randomly selected. ${ }^{26}$ A similar recruitment process was chosen in the prospective cohort study by Ma et al. ${ }^{31}$ Here, pupils from 6 primary schools in the Baoshan district of Shanghai were randomly selected. The school selection in the prospective cohort study by $\mathrm{Wu}$ et al in Beijing was also randomized. ${ }^{33}$ In contrast, the Myopic Investigation Study from Taipei (prospective cohort study) originally included all second graders of the whole city (initially $n=11,590) .{ }^{29}$ In Delhi, 20 schools previously selected by randomization for a cross-sectional study were considered for study participation in the prospective cohort study. ${ }^{32,34}$

The two randomized controlled intervention studies selected participants by random process. He et al formed 6 strata out of 29 primary schools in Guangzhou and then randomly selected two schools from each one, one for the control and one for the intervention group. ${ }^{22} \mathrm{Wu}$ et al used a similar procedure. ${ }^{24}$ They first selected one or two cities from each of the four geographical areas (north, central, west and south) of Taiwan. This was done in order to have more balanced preconditions regarding the weather in the different regions. Secondly, four schools of the six cities were randomly selected, and the 24 schools were thereafter randomly assigned to the intervention or control group. Nevertheless, in the end only 16 randomly selected schools participated in this randomized controlled trial, since eight schools
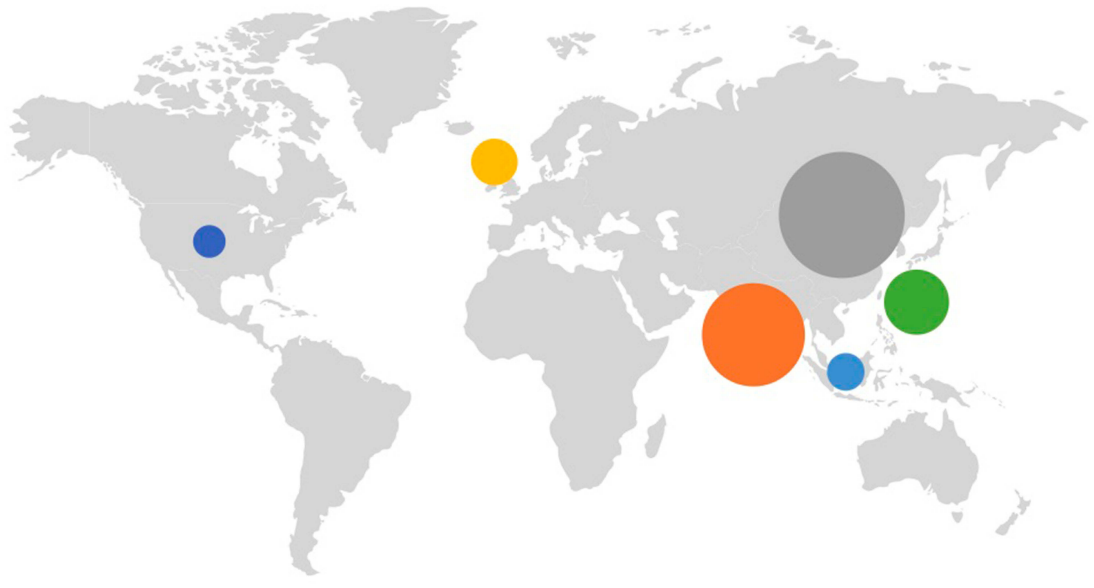

\begin{tabular}{|l|r|r|}
\hline Country & n & $\%$ \\
\hline USA & 835 & 3 \\
\hline India & 9616 & 30 \\
\hline China & 14727 & 45 \\
\hline UK & 2005 & 6 \\
\hline Singapore & 1249 & 4 \\
\hline Taiwan & 3949 & 12 \\
\hline Total & 32381 & 100 \\
\hline
\end{tabular}

Figure 3 Tabular listing of sample sizes by country where the included studies were conducted, complemented by a geographical overview. 


\begin{tabular}{|c|c|c|c|c|c|c|c|}
\hline 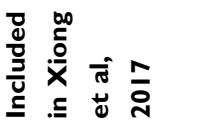 & & 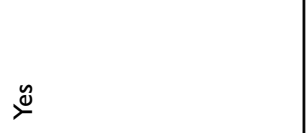 & $\stackrel{\circ}{z}$ & & $\stackrel{\circ}{z}$ & $\stackrel{\tilde{y}}{\tau}$ & $\stackrel{\circ}{z}$ \\
\hline 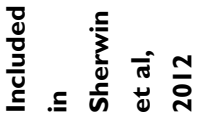 & & $\stackrel{\check{\Perp}}{\nearrow}$ & i & & $\stackrel{\circ}{z}$ & ì & ㅇ \\
\hline 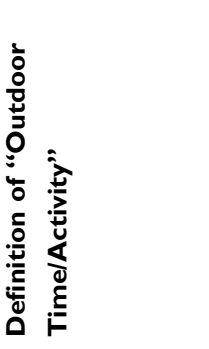 & & 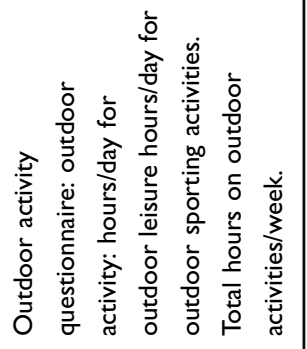 & 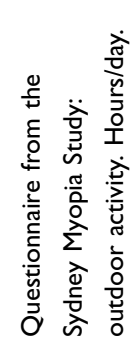 & & 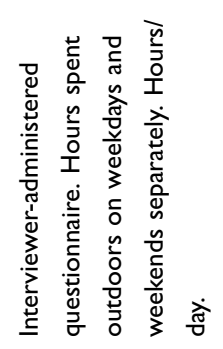 & 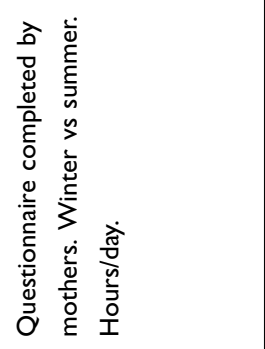 & 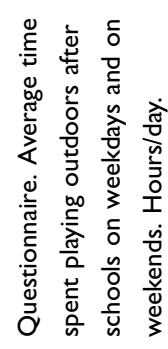 \\
\hline 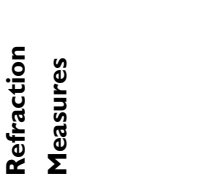 & & 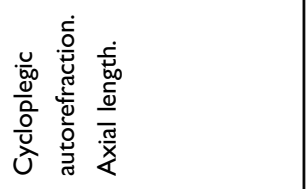 & 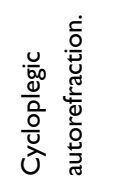 & & 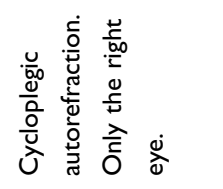 & 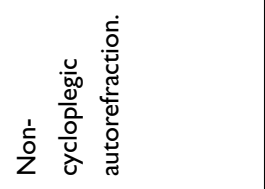 & 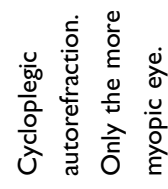 \\
\hline 范 & & 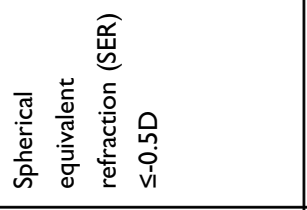 & & & 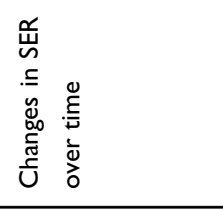 & 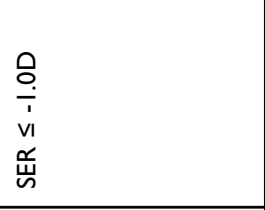 & 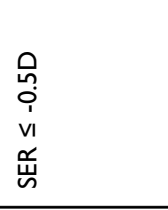 \\
\hline 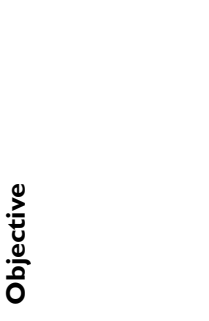 & & 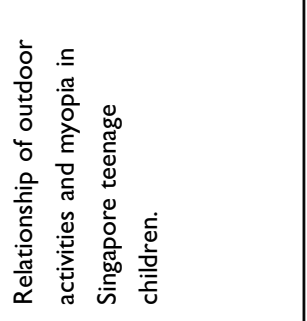 & 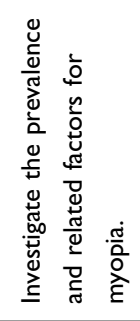 & & 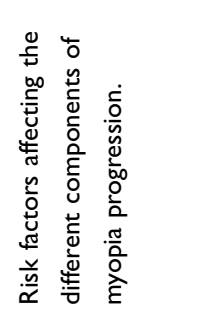 & 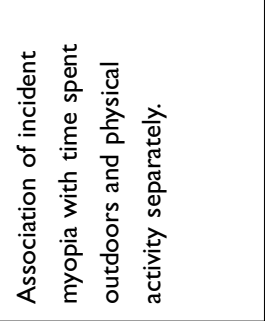 & 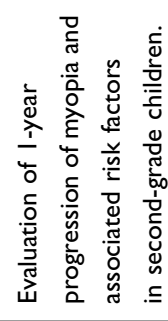 \\
\hline 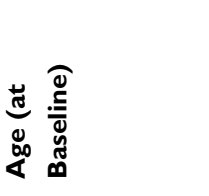 & & 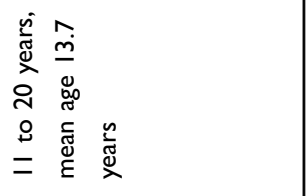 & 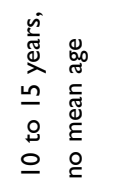 & & 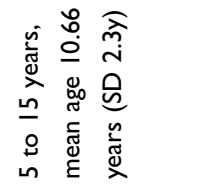 & 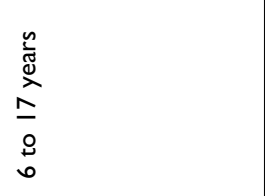 & 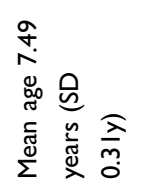 \\
\hline 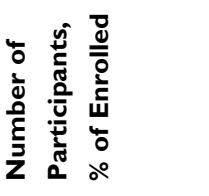 & & 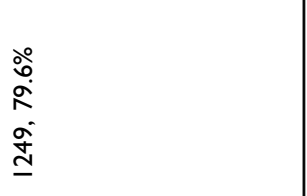 & 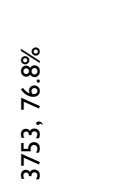 & & $\begin{array}{l}\stackrel{\circ}{\infty} \\
\text { oे } \\
\hat{\sigma} \\
\hat{0}\end{array}$ & 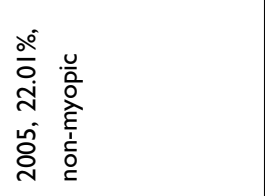 & 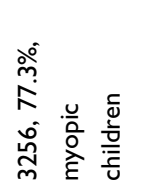 \\
\hline 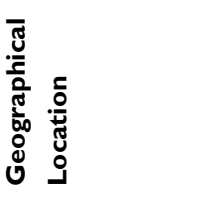 & $\stackrel{\mathscr{\Xi}}{\overline{0}}$ & 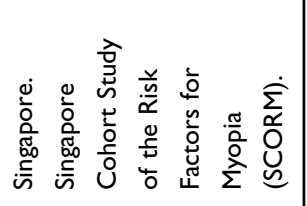 & 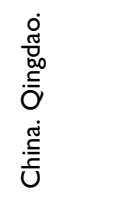 & 兽 & 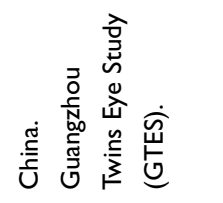 & 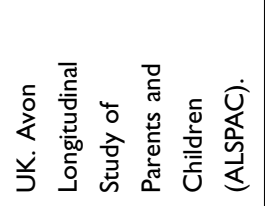 & 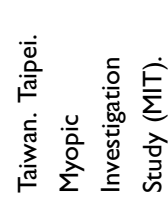 \\
\hline $\begin{array}{l}\text { ते } \\
\text { जे }\end{array}$ & 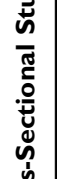 & 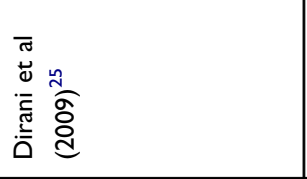 & 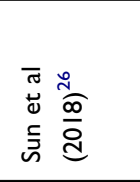 & 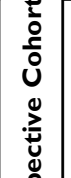 & 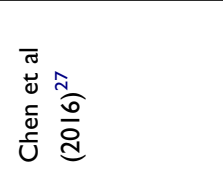 & 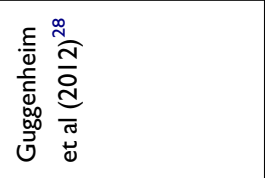 & 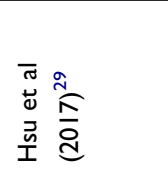 \\
\hline$\dot{\mathbf{z}}$ & ปั & - & $N$ & $\frac{1}{0}$ & $m$ & $\sigma$ & in \\
\hline
\end{tabular}




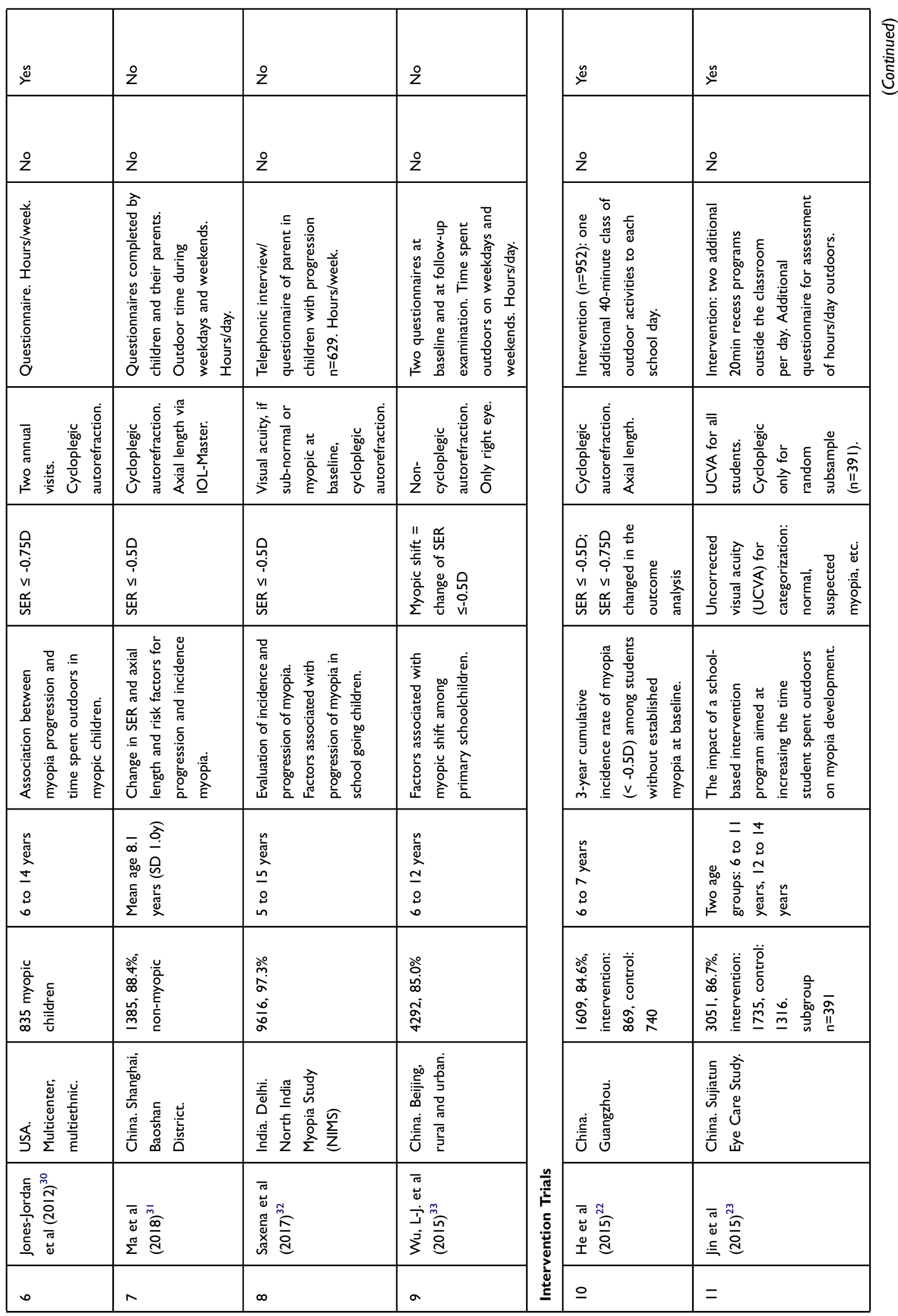




\begin{tabular}{|c|c|}
\hline 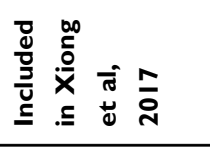 & zo \\
\hline 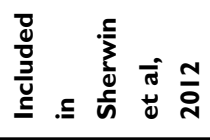 & zo \\
\hline 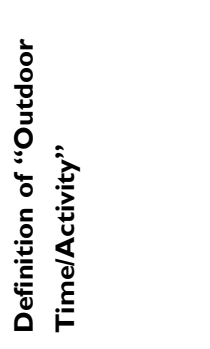 & 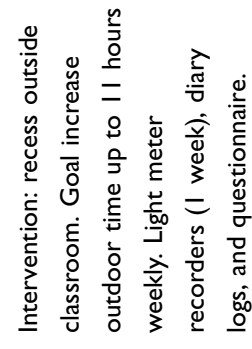 \\
\hline 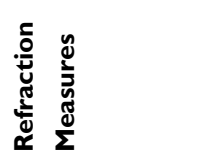 & 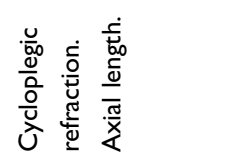 \\
\hline 竞 & 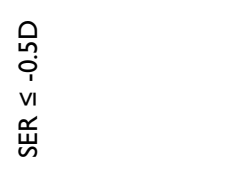 \\
\hline : & 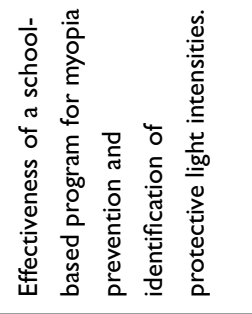 \\
\hline 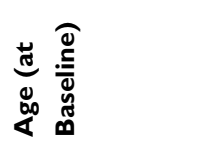 & 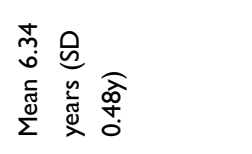 \\
\hline 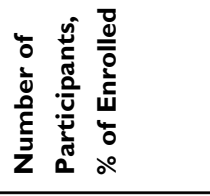 & 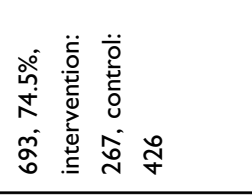 \\
\hline 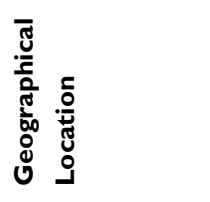 & 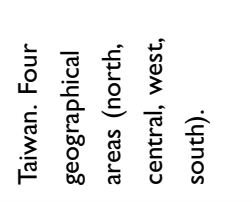 \\
\hline $\begin{array}{l}\text { ते } \\
\text { मे }\end{array}$ & 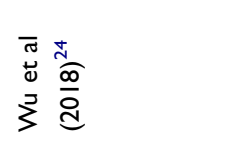 \\
\hline$\dot{\mathbf{z}}$ & $\simeq$ \\
\hline
\end{tabular}

withdrew from the program shortly before the beginning of the trial. For the third controlled intervention study, two primary schools and two junior high schools in urban and rural areas of Sujiatun were selected, without further specification about the selection process. ${ }^{23}$

Measurement Methods of Exposure (Outdoor Time) and Outcome (Myopia)

Outdoor time was assessed almost exclusively by questionnaire, mainly completed by the parents of participating children. Furthermore, the definition of outdoor time exposure differed between the included studies. In the majority of the cases an average daily amount of time outdoors was inquired. $^{22,23,26-29,31,33}$ In the remaining four studies the estimated number of hours per week was used for the statistical analysis. ${ }^{24,25,30,32}$ Only in the study of Wu et al a more objective measurement of time outdoor was performed using a wearable light intensity measurement device for one week. ${ }^{24}$

As previously described in the section about the selection criteria, objective measurements of myopia were required; the refraction measurements were performed with cycloplegia in most (10/12) studies.

\section{Potential Biases in the Included Studies}

Included studies were analysed for potential biases and an overview of the major limitations of the individual publications is given in Table 3. In summary, all of the included studies show a common problem of report or recall bias about the exposure (outdoor light).

\section{Effect Estimate of the Association}

Only studies with calculated association estimates were included. In the majority of the observational studies, multivariate analyses were performed and odds ratios indicated. The estimates from every study are listed in the column "statistical association" of Table 3 and presented in further detail in the last section of the results. Also listed in Table 3 under "covariates for adjustment", are the reported factors used to adjust the estimates. For example, in nine of the selected studies, an adjustment for the factor of parental myopia was described. ${ }^{23-26,28,29,31-33}$ However the definition and measurement of this factor varied between studies, for example, Saxena et al took into account whether a participant's parent wears distance glasses. ${ }^{32}$

\section{Comparison of the Prevalence and Incidence Rates of Myopia}

Myopia prevalence and/or progression rates, as well as calculated hours on outdoor activities per day or week 
Table 3 Study Outcomes, Part I

\begin{tabular}{|c|c|c|c|c|c|c|c|}
\hline No. & Study & $\begin{array}{l}\text { Myopia } \\
\text { Prevalence/ } \\
\text { Progression }\end{array}$ & $\begin{array}{l}\text { Time Outdoors } \\
\text { Hours/Day or } \\
\text { Hours/Week }\end{array}$ & $\begin{array}{l}\text { Statistical } \\
\text { Association }\end{array}$ & $\begin{array}{l}\text { Covariates for } \\
\text { Adjustment }\end{array}$ & Limitations & $\begin{array}{l}\text { Effect - } \\
\text { Summary }\end{array}$ \\
\hline \multicolumn{8}{|c|}{ Cross-Sectional Studies } \\
\hline 1 & $\begin{array}{l}\text { Dirani et al } \\
(2009)^{25}\end{array}$ & $69.5 \%(868 / 1249)$ & $\begin{array}{l}3.09 \pm \text { SD } 1.92 \mathrm{~h} / \mathrm{d} \text { vs } \\
3.59 \pm \text { SD } 2.03 \mathrm{~h} / \mathrm{d} \text {, } \\
\mathrm{p}<0.00 \text { I in myopic vs } \\
\text { non-myopic. }\end{array}$ & $\begin{array}{l}\mathrm{OR}=0.90(95 \% \mathrm{Cl} \\
0.84-0.96 ; p=0.004)\end{array}$ & $\begin{array}{l}\text { Age, gender, } \\
\text { ethnicity, school, } \\
\text { books read per } \\
\text { week, height and } \\
\text { parental myopia, } \\
\text { father's education } \\
\text { level, IQ. }\end{array}$ & $\begin{array}{l}\text { Report bias, highly } \\
\text { selected population, } \\
\text { role of physical } \\
\text { activity, no } \\
\text { longitudinal data. }\end{array}$ & Protective \\
\hline 2 & $\begin{array}{l}\text { Sun et al } \\
(2018)^{26}\end{array}$ & $\begin{array}{l}52.02 \%(2544 / 4890) \\
\text { Mean refraction error } \\
-1.62( \pm 1.82 D)\end{array}$ & $\begin{array}{l}\text { Between } 1.42 \pm 0.96 \mathrm{~h} / \\
\mathrm{d}(\text { age } 15 \mathrm{y} \text { ) and } 2.28 \\
\pm 1.2 \mathrm{lh} / \mathrm{d} \text { (at age } 10 \mathrm{y})\end{array}$ & $\begin{array}{l}\mathrm{OR}=0.74(95 \% \mathrm{Cl} \\
0.53-0.92 ; \mathrm{p}<0.00 \mathrm{I}) \\
\text { (multivariate analysis), } \\
\mathrm{OR}=0.67 \\
(0.46-0.78 ; \mathrm{p}=0.03) \\
\text { (univariate analysis). }\end{array}$ & $\begin{array}{l}\text { NS, other variables } \\
\text { in the analysis: age, } \\
\text { gender, parental } \\
\text { myopia, near work } \\
\text { distance, near work } \\
\text { time. }\end{array}$ & $\begin{array}{l}\text { Report bias, data } \\
\text { collection for } \\
\text { cycloplegic } \\
\text { autorefraction lasted } \\
2 \text { month, no } \\
\text { longitudinal data. }\end{array}$ & Protective \\
\hline \multicolumn{8}{|c|}{ Prospective Cohort Studies } \\
\hline 3 & $\begin{array}{l}\text { Chen et al } \\
(2016)^{27}\end{array}$ & $\begin{array}{l}\text { Mean SER at baseline } \\
\text { was }-0.52 \mathrm{D} \text { (SD } \\
\pm 1.97 \mathrm{D}) \text {. Annual } \\
\text { progression according } \\
\text { to clusters: "stable" } \\
-0.08 \pm 0.08 \mathrm{D} \text {, "slow" } \\
-0.31 \pm 0.07 \mathrm{D} \text {, "fast" } \\
-0.58 \pm 0.13 \mathrm{D} \text {. }\end{array}$ & $\begin{array}{l}\text { Cluster "stable": } 0.89 \\
( \pm I .2 I) h / d, \text { cluster } \\
\text { "slow": } 0.97( \pm I .14) \mathrm{h} / \\
\text { d, cluster "fast": } 0.95 \\
( \pm I . I I) h / d .\end{array}$ & $\begin{array}{l}\text { Principal component } \\
\text { analysis (PCA), } \\
\text { negative association } \\
\text { with component } 3 \\
\text { ("stabilization"). Late } \\
\text { onset of refraction } \\
\text { progress was } \\
\text { associated with } \\
\text { increased outdoor } \\
\text { time, } p=0.0422 .\end{array}$ & $\begin{array}{l}\text { Age, baseline } \\
\text { refraction. }\end{array}$ & $\begin{array}{l}\text { Significant differences } \\
\text { in the baseline } \\
\text { characteristics among } \\
\text { the different clusters. } \\
\text { Novel usage of } \\
\text { statistical model for } \\
\text { evaluation of data. } \\
\text { Selective cohort. } \\
\text { Report bias. }\end{array}$ & $\begin{array}{l}\text { Late } \\
\text { myopia } \\
\text { onset }\end{array}$ \\
\hline 4 & $\begin{array}{l}\text { Guggenheim } \\
\text { et al }(2012)^{28}\end{array}$ & $\begin{array}{l}\text { Prevalence at baseline } \\
\text { (age 6y): I3.6\% (I236/ } \\
9109) . \text { Children who } \\
\text { became myopic after } \\
\text { age IIy: 14.0\% (28I/ } \\
2005) .\end{array}$ & $\begin{array}{l}\text { Grouping "low" time } \\
\text { outdoors <3h/d vs } \\
\text { "high" >3h/d. }\end{array}$ & $\begin{array}{l}\text { Prediction of incident } \\
\text { myopia OR }=0.65 \\
(95 \% \mathrm{Cl} 0.45-0.96) \text {. } \\
\text { (Logistic regression } \\
\text { analysis for children } \\
\text { who were non- } \\
\text { myopic at age I lyears } \\
(n=2005)) .\end{array}$ & $\begin{array}{l}\text { Parental myopia, } \\
\text { time reading, gender, } \\
\text { physical activity/ } \\
\text { sedentary behavior } \\
\text { and constant. }\end{array}$ & $\begin{array}{l}\text { Non-cycloplegic } \\
\text { autorefraction. } \\
\text { Report bias. Loss-to } \\
\text { follow up. Unclear } \\
\text { how many hours/day } \\
\text { outdoor time at aged } \\
\text { II years when OR } \\
\text { was estimated. }\end{array}$ & Protective \\
\hline 5 & $\begin{array}{l}\text { Hsu et al } \\
(2017)^{29}\end{array}$ & $\begin{array}{l}\text { Grouping according } \\
\text { to progression } \\
\text { velocity: slow change } \\
\text { of SER max. }-0.5 \mathrm{D} / \mathrm{y} \text {, } \\
\text { moderate SER change } \\
\text { of }-0.5 \text { to }-1.0 \mathrm{D} / \mathrm{y} \text {, } \\
\text { fast SER change of } \\
\text { more than }-1.0 \mathrm{D} / \mathrm{y} \text {. } \\
\text { No difference in } \\
\text { urban vs Suburban. }\end{array}$ & $\begin{array}{l}\text { Two subcategories: } \\
\text { outdoor activities on } \\
\text { weekdays < lh/day vs } \\
>\text { Ih/day; on } \\
\text { weekends < } 2 \text { h/day vs } \\
>2 \text { h/day. }\end{array}$ & $\begin{array}{l}\text { For weekdays in the } \\
\text { moderate } \\
\text { progression group: } \\
\mathrm{OR}=0.98 \text { ( } 95 \% \mathrm{Cl} \\
0.79-1.22) \text {. In the fast } \\
\text { progression group: } \\
\text { OR=I.2I (95\% Cl } \\
0.95-1.55) .\end{array}$ & $\begin{array}{l}\text { NS, other variables } \\
\text { in the analysis: age } \\
\text { when starting near } \\
\text { work, gender, } \\
\text { parental myopia, } \\
\text { baseline SE, time } \\
\text { spent on near work, } \\
\text { cycloplegic } \\
\text { treatment, etc. }\end{array}$ & $\begin{array}{l}\text { Cycloplegia } \\
\text { treatment during } \\
\text { observation time. } \\
\text { Variations of eye } \\
\text { examination } \\
\text { procedures. Report } \\
\text { bias. Children with } \\
\text { fast annual myopia } \\
\text { progression were } \\
\text { more myopic at } \\
\text { baseline and had } \\
\text { a shorter reading } \\
\text { distance. }\end{array}$ & $\begin{array}{l}\text { No } \\
\text { association }\end{array}$ \\
\hline
\end{tabular}


Table 3 (Continued).

\begin{tabular}{|c|c|c|c|c|c|c|c|}
\hline No. & Study & $\begin{array}{l}\text { Myopia } \\
\text { Prevalence/ } \\
\text { Progression }\end{array}$ & $\begin{array}{l}\text { Time Outdoors } \\
\text { Hours/Day or } \\
\text { Hours/Week }\end{array}$ & $\begin{array}{l}\text { Statistical } \\
\text { Association }\end{array}$ & $\begin{array}{l}\text { Covariates for } \\
\text { Adjustment }\end{array}$ & Limitations & $\begin{array}{l}\text { Effect - } \\
\text { Summary }\end{array}$ \\
\hline 6 & $\begin{array}{l}\text { Jones-Jordan } \\
\text { et al }(2012)^{30}\end{array}$ & $\begin{array}{l}\text { Only myopic children } \\
\text { included. Average age } \\
\text { of myopia onset } \\
\text { I0.4years }(S D=1.8 y) \text {, } \\
\text { mean } S E-I .82 D \\
(S D=1.06) \text {. Annual } \\
\text { rate of progression } \\
-0.39 D(S D=0.32 D) \text {. }\end{array}$ & $\begin{array}{l}\text { Threshold effect, at } \\
\text { least } 9 \text { hours of } \\
\text { outdoor activity per } \\
\text { week necessary to } \\
\text { see an effect. }\end{array}$ & $\begin{array}{l}\text { Outdoor/sports } \\
\text { activity did not have } \\
\text { significant univariate } \\
\text { associations with } \\
\text { progression. } \\
\text { OR=2.67 ( } 95 \% \mathrm{Cl} \\
\text { I.75-4.06) for at least } \\
9 \text { hours/week } \\
\text { threshold. }\end{array}$ & $\begin{array}{l}\text { NS, other variables } \\
\text { in the analysis: } \\
\text { average hours of } \\
\text { reading for pleasure, } \\
\text { average hours of TV, } \\
\text { average hours of } \\
\text { studying, etc. }\end{array}$ & $\begin{array}{l}\text { Report bias. } \\
\text { Misclassification bias: } \\
\text { unclear how many } \\
\text { participants were } \\
\text { excluded because of } \\
\text { unrealistic } \\
\text { questionnaire } \\
\text { responses. Missing } \\
\text { power analysis. }\end{array}$ & $\begin{array}{l}\text { Not } \\
\text { protective } \\
\text { following } \\
\text { onset }\end{array}$ \\
\hline 7 & $\begin{array}{l}\text { Ma et al } \\
(2018)^{31}\end{array}$ & $\begin{array}{l}\text { Among } 7 \text { year old } \\
\text { children prevalence } \\
\text { II.3\%, among II year } \\
\text { old children } 52.9 \% \text {. } \\
\text { Number of children } \\
\text { with newly developed } \\
\text { myopia in } 2 \text { years/ } \\
\text { number of children at } \\
\text { baseline was } 30 \% \\
\text { (I70/566), } 29.2 \% \\
\text { (I82/624) and } 33.2 \% \\
(149 / 449) \text { for grades } \\
\text { I, 2, and } 3 \text {. }\end{array}$ & $\begin{array}{l}\text { Three categories } \\
\text { defined at baseline: } \\
\text { low }=<4 \mathrm{~h} / \text { week, } \\
\text { moderate }=4-9 \mathrm{~h} / \\
\text { week, high }=>9 \mathrm{~h} / \\
\text { week. Average time } \\
\text { spent outdoors was } \\
0.76 \mathrm{~h} / \text { day, } 0.8 \mathrm{lh} / \text { day } \\
\text { and } 0.89 \mathrm{~h} / \text { day at } \\
\text { weekdays for children } \\
\text { of grades I, } 2,3 . \text { On } \\
\text { the weekend: } 1.9 \mathrm{lh} / \\
\text { day, I.82h/day and } \\
\text { I.95h/day. }\end{array}$ & $\begin{array}{l}\mathrm{OR}=1.12(95 \% \mathrm{Cl} \\
0.77-1.64) \text {. Logistic } \\
\text { regression showed } \\
\text { that the 2-year } \\
\text { incident myopia was } \\
\text { only associated with } \\
\text { parental myopia. }\end{array}$ & $\begin{array}{l}\text { Age, gender, parental } \\
\text { myopia and baseline } \\
\text { SER in multivariate } \\
\text { logistic regression } \\
\text { analysis }\end{array}$ & $\begin{array}{l}\text { Small variations of } \\
\text { time of outdoor } \\
\text { activity. Report bias. } \\
\text { Questionnaires } \\
\text { collected only at } \\
\text { baseline. }\end{array}$ & $\begin{array}{l}\text { No } \\
\text { association }\end{array}$ \\
\hline 8 & $\begin{array}{l}\text { Saxena et al } \\
(2017)^{32}\end{array}$ & $\begin{array}{l}\text { Prevalence } 1297 \\
(13.1 \%, 1297 / 9884) \text { at } \\
\text { baseline. } 8200 \text { with } \\
\text { normal UCVA at } \\
\text { baseline, of these } 275 \\
\text { developed myopia } \\
\text { after one year: } \\
\text { Incidence } 3.4 \% \text { (SE } \\
0.2,95 \% \mathrm{Cl} 3.0-3.8) \text {, } \\
\text { myopic progression in } \\
49.2 \% \text { of children. }\end{array}$ & $\begin{array}{l}\text { Mean outdoor } \\
\text { activity } 13.95 \pm 1.9 \mathrm{~h} / \\
\text { week, range } 8-24 \mathrm{~h} / \\
\text { week. }\end{array}$ & $\begin{array}{l}\text { OR }=0.54(95 \% \mathrm{Cl} \\
0.37-0.79 ; \mathrm{p}=0.002) \\
\text { for } \leq 14 \mathrm{~h} / \text { week } \\
\text { versus }>14 \mathrm{~h} / \text { week, } \\
\text { slower progression in } \\
\text { the group with higher } \\
\text { increased outdoor } \\
\text { activity. }\end{array}$ & $\begin{array}{l}\text { Age, gender, type of } \\
\text { school, } \\
\text { socioeconomic } \\
\text { status, parental use } \\
\text { of distance } \\
\text { spectacles, hours of } \\
\text { reading/writing at } \\
\text { school and home, } \\
\text { etc. }\end{array}$ & $\begin{array}{l}\text { Misclassification bias: } \\
\text { cycloplegic refraction } \\
\text { only in children with } \\
\text { VA <6/9.5. Report } \\
\text { bias. Rather short } \\
\text { follow-up time of } \\
\text { one year. }\end{array}$ & Protective \\
\hline 9 & $\begin{array}{l}\text { Wu, L-J. et al } \\
(2015)^{33}\end{array}$ & $\begin{array}{l}\text { Mean refractive error } \\
\text { after one year was } \\
-1.13 \pm 1.57 \mathrm{D} \text {, } \\
\text { changed by a mean of } \\
-0.52 \pm 0.73 \mathrm{D} \text {. Myopic } \\
\text { progression in } 51.0 \% \\
(\mathrm{n}=2170) \text { by } \leq-0.5 \mathrm{D} \text {. }\end{array}$ & $\begin{array}{l}\text { Time outdoor for } \\
\text { leisure (h/day) in } \\
\text { children without } \\
\text { myopic shift: } 1.03 \\
\pm 0.65 \text { vs } 1.40 \pm 0.70 \\
\text { for children with } \\
\text { myopic shift } \\
\text { ( } \mathrm{p}=0.00 \mathrm{I}) \text {. But for } \\
\text { time outdoors for } \\
\text { sports } 0.89 \pm 0.61 \mathrm{vs} \\
0.86 \pm 0.66, \text { no } \\
\text { difference } p=0.154 \text {. }\end{array}$ & $\begin{array}{l}\mathrm{OR}=0.87,(95 \% \\
\mathrm{Cl}=0.78-0.97 \\
\mathrm{P}<0.013) \text { for outdoor } \\
\text { leisure (adjusted for } \\
\text { all covariates), but } \\
\text { not for outdoor } \\
\text { sports } \mathrm{OR}=1.09 \\
(95 \% \mathrm{Cl}=0.97-1.22 \text {, } \\
\mathrm{P}=0.135) \text { (adjusted } \\
\text { only for sex and age). }\end{array}$ & $\begin{array}{l}\text { Age, gender, region } \\
\text { of habitation, } \\
\text { parental myopia, } \\
\text { refractive status at } \\
\text { baseline. }\end{array}$ & $\begin{array}{l}\text { Noncycloplegic } \\
\text { refraction. Report } \\
\text { bias. Chinese length } \\
\text { measurement in unit } \\
\text { of "Chi". Loss-to } \\
\text { follow-up. }\end{array}$ & Protective \\
\hline
\end{tabular}

(Continued) 
Table 3 (Continued).

\begin{tabular}{|c|c|c|c|c|c|c|c|}
\hline No. & Study & $\begin{array}{l}\text { Myopia } \\
\text { Prevalence/ } \\
\text { Progression }\end{array}$ & $\begin{array}{l}\text { Time Outdoors } \\
\text { Hours/Day or } \\
\text { Hours/Week }\end{array}$ & $\begin{array}{l}\text { Statistical } \\
\text { Association }\end{array}$ & $\begin{array}{l}\text { Covariates for } \\
\text { Adjustment }\end{array}$ & Limitations & $\begin{array}{l}\text { Effect - } \\
\text { Summary }\end{array}$ \\
\hline \multicolumn{8}{|c|}{ Study Outcomes, Part II } \\
\hline \multicolumn{8}{|c|}{ Controlled Intervention Trials } \\
\hline 10 & $\begin{array}{l}\text { He et al } \\
(2015)^{22}\end{array}$ & $\begin{array}{l}3 \text {-year cumulative } \\
\text { incidence rate of } \\
\text { myopia }(<-0.5 \mathrm{D}) \text { in } \\
\text { the intervention } \\
\text { group: } 30.4 \% \text { vs in the } \\
\text { control group: } 39.5 \% \text {. }\end{array}$ & $\begin{array}{l}\text { Additional } 40 \text {-minute } \\
\text { class of outdoor } \\
\text { activities was added } \\
\text { to each school day. } \\
\text { Similar amounts of } \\
\text { time spent outdoors } \\
\text { of school hours in } \\
\text { both groups } \\
\text { (intervention vs } \\
\text { control) and in every } \\
\text { grade (eg } 68.04 \mathrm{~min} / \\
\text { day vs } 66.42 \mathrm{~min} / \text { day). }\end{array}$ & $\begin{array}{l}\text { OR=0.73 }(95 \% \mathrm{Cl} \text {, } \\
0.57-0.92, \mathrm{p}=0.0 \mathrm{I}) \\
\text { for the } 3 \text {-year } \\
\text { incidence rate of } \\
\text { myopia. Significant } \\
\text { change also in } \\
\text { spherical equivalent. } \\
\text { But elongation of } \\
\text { axial length was not } \\
\text { significantly different } \\
\text { between the } \\
\text { intervention group } \\
\text { and the control } \\
\text { group. } \\
\text { Successful implication } \\
\text { of the outdoor class } \\
\text { observed in } 83.5 \% \text {. }\end{array}$ & $\begin{array}{l}\text { NS, other variables } \\
\text { in the analysis: age, } \\
\text { gender, weight, } \\
\text { height, uncorrected } \\
\text { visual acuity, etc. }\end{array}$ & $\begin{array}{l}\text { No masking of } \\
\text { examiners. } \\
\text { Proportion of parents } \\
\text { with myopia was } \\
\text { lower in the } \\
\text { intervention group. } \\
\text { Sample size } \\
\text { estimation was based } \\
\text { on } 50 \% \text { reduction of } \\
\text { incident myopia. } \\
\text { Incomplete } \\
\text { participation due to } \\
\text { refusal of cycloplegic } \\
\text { refraction. Change of } \\
\text { myopia definition for } \\
\text { primary outcome. No } \\
\text { objective outdoor } \\
\text { time measurement. }\end{array}$ & Protective \\
\hline II & $\begin{array}{l}\text { Jin et al } \\
(2015)^{23}\end{array}$ & $\begin{array}{l}\text { Significant changes in } \\
\text { UCVA after I-year of } \\
\text { follow up between } \\
\text { intervention and } \\
\text { control group, but } \\
\text { not between myopia } \\
\text { and non-myopia } \\
\text { suspected. Subgroup } \\
\text { analysis: Incidence of } \\
\text { new myopia onset } \\
\text { lower in the } \\
\text { intervention group } \\
\text { than in the control } \\
\text { group } 3.70 \% \text { vs } \\
8.50 \% \text {. Also changes } \\
\text { in axial length were } \\
\text { significantly lower in } \\
\text { the intervention } \\
\text { group ( } 0.16+-0.3 \mathrm{~mm} / \\
\text { year vs } 0.21 \\
\pm 0.21 \mathrm{~mm} / \mathrm{y}, \mathrm{P}= \\
0.034) \text {. }\end{array}$ & $\begin{array}{l}\text { According to } \\
\text { questionnaire similar } \\
\text { outdoor activity } \\
\text { between intervention } \\
\text { and control group. } \\
\text { Intervention } \\
\text { additional } 2 \times 20 \mathrm{~min} \\
\text { outdoor recess. }\end{array}$ & $\begin{array}{l}\text { Comparison of mean } \\
\text { UCVA between } \\
\text { groups. Multivariate } \\
\text { analysis of variance of } \\
\text { mean uncorrected } \\
\text { visual acuity during } \\
\text { the I-year follow-up } \\
\text { period: showed } \\
\text { statistical significance } \\
\text { with the intervention } \\
\text { group having a better } \\
\text { UCVA. Subgroup } \\
\text { analysis showed } \\
\text { lower cumulative } \\
\text { incidence of myopia } \\
\text { in the intervention } \\
\text { group. }\end{array}$ & $\begin{array}{l}\text { NS, other variables } \\
\text { in the analysis: age, } \\
\text { gender, region of } \\
\text { habitation, parental } \\
\text { myopia, parental } \\
\text { education, family } \\
\text { income. }\end{array}$ & $\begin{array}{l}\text { Intervention group } \\
\text { had more myopic } \\
\text { parents, higher } \\
\text { parental education } \\
\text { and higher individual } \\
\text { income. Differences } \\
\text { between groups. } \\
\text { Only small subgroup } \\
\text { underwent } \\
\text { cycloplegic refraction } \\
\text { examination. No } \\
\text { objective outdoor } \\
\text { time measurement. } \\
\text { No information on } \\
\text { performance of the } \\
\text { additional recess } \\
\text { time. }\end{array}$ & Protective \\
\hline
\end{tabular}

(Continued) 
Table 3 (Continued).

\begin{tabular}{|c|c|c|c|c|c|c|c|}
\hline No. & Study & $\begin{array}{l}\text { Myopia } \\
\text { Prevalence/ } \\
\text { Progression }\end{array}$ & $\begin{array}{l}\text { Time Outdoors } \\
\text { Hours/Day or } \\
\text { Hours/Week }\end{array}$ & $\begin{array}{l}\text { Statistical } \\
\text { Association }\end{array}$ & $\begin{array}{l}\text { Covariates for } \\
\text { Adjustment }\end{array}$ & Limitations & $\begin{array}{l}\text { Effect - } \\
\text { Summary }\end{array}$ \\
\hline 12 & $\begin{array}{l}\text { Wu et al } \\
(2018)^{24}\end{array}$ & $\begin{array}{l}\text { Incidence of myopia } \\
\text { in the intervention } \\
\text { group } 14.47 \% \text { vs } \\
17.40 \% \text { in the control } \\
\text { group. The } \\
\text { intervention group } \\
\text { showed significantly } \\
\text { less myopic shift and } \\
\text { axial elongation } \\
\text { compared with the } \\
\text { control group ( } 0.35 \mathrm{D} \\
\text { vs } 0.47 \mathrm{D} ; 0.28 \text { vs } \\
0.33 \mathrm{~mm} ; \mathrm{p}=0.002 \\
\text { and } \mathrm{p}=0.003 \text { ) and } \\
\text { a } 54 \% \text { lower risk of } \\
\text { rapid myopia } \\
\text { progression. }\end{array}$ & $\begin{array}{l}\text { In the intervention } \\
\text { group significant } \\
\text { higher percentage of } \\
\text { participants who } \\
\text { spent more than IIh } \\
\text { outdoor per week. }\end{array}$ & $\begin{array}{l}\mathrm{OR}=0.65(95 \% \mathrm{Cl} \\
0.42-1.01) . \text { For } \\
\text { progression: the } \\
\text { intervention group } \\
\text { had slower myopic } \\
\text { shift than the control } \\
\text { group }(21.7 \% \text { vs } \\
31.0 \%), \mathrm{OR}=0.46 \\
(95 \% \mathrm{Cl}, 0.28-0.77 \text {; } \\
\mathrm{P}=0.003) . \\
\text { Average classroom } \\
\text { clearance in the } \\
\text { intervention group } \\
\text { was } 81.29 \% \text {, in the } \\
\text { control group } 61.1 \% \text {. }\end{array}$ & $\begin{array}{l}\text { NS, other variables } \\
\text { in the analysis: age, } \\
\text { gender, area, } \\
\text { parental myopia, } \\
\text { total sun hours } \\
\text { during light meter } \\
\text { wearing week. }\end{array}$ & $\begin{array}{l}\text { Short observation } \\
\text { time. } 8 \text { schools } \\
\text { withdrew from study } \\
\text { after randomization. } \\
\text { Objective light } \\
\text { measurement only } \\
\text { for one week. Report } \\
\text { bias. Other programs } \\
\text { at the same time } \\
\text { ongoing for myopia } \\
\text { prevention. } \\
\text { Classroom clearance } \\
\text { only } 20 \% \text { more in the } \\
\text { intervention group } \\
\text { compared to control. }\end{array}$ & $\begin{array}{l}\text { Slower } \\
\text { progression }\end{array}$ \\
\hline
\end{tabular}

are summarized in Table 3. The observed prevalences exhibited regional and age-related differences. In studies with participants older than 10 years myopia prevalence rates ranged from $13.1 \%$ in Delhi, ${ }^{32} 14.0 \%$ in the UK, to $52.02 \%$ in Qingdao ${ }^{26}$ and $52.9 \%$ in Shanghai ${ }^{31}$ and up to $69.5 \%$ in Singapore. ${ }^{25}$

In the randomized controlled trial by $\mathrm{He}$ et al the 3 -year cumulative incidence rate of myopia in the intervention group was $30.4 \%$ compared to $39.5 \%$ in the control group. ${ }^{22}$ The subgroup analysis in the Sujiatun Eye Care Study found a myopia incidence of $3.7 \%$ in the intervention group versus $8.5 \%$ in the control group after one year. $\mathrm{Wu}$ et al found $14.47 \%$ in the intervention group and $17.40 \%$ in the control group. ${ }^{24}$

\section{Comparison of Outdoor Time in the Different Studies}

As mentioned above, time outdoors was established with a range of questionnaires in all observational studies; time periods of less than one hour per day, eg, 0.76 hours/day for first-grade students in Shanghai on weekdays and up to a maximum of 3.39 hours/day for weekdays and weekends together were calculated. ${ }^{25,31}$ The detailed information can be found in Tables 2 and 3 in the column "Time outdoors hours/day or hours/week".

\section{Comparison of Estimates of Association Between Outdoor Time and Myopia of the Included Studies}

The association estimates, in the form of odds ratios (including 95\% CIs) if available, are indicated for every individual study in Table 3 . Five of the nine cross-sectional and prospective cohort studies indicate an inverse association of time spent outdoors and myopia onset. To be precise, the two cross-sectional studies showed adjusted odds ratios of $\mathrm{OR}=0.90$ (95\% CI $0.84-0.96 ; \mathrm{p}=0.004)$ and $\mathrm{OR}=0.74$ (95\% CI $0.53-0.92$; $\mathrm{p}<0.001) .{ }^{25,26}$ Chen et al used a principle component analysis and observed a later onset of myopia with more time spent outdoors. ${ }^{27}$ Estimates of Guggenheim et $\mathrm{al}^{28}$ as well as Saxena et $\mathrm{al}^{32}$ also indicated odds ratios of $<1.0 \quad(\mathrm{OR}=0.65 \quad(95 \%$ CI $\quad 0.45-0.96)$ and $\mathrm{OR}=0.54(95 \%$ CI $0.37-0.79 ; \mathrm{p}=0.002))$, respectively. No association with time outdoors were found in the prospective cohort studies by Jones-Jordan et al, ${ }^{30} \mathrm{Ma}$ et $\mathrm{al}^{31}$ and $\mathrm{Hsu}$ et $\mathrm{al}^{29}$

No retardation in myopia progression could be observed in children with pre-existing myopia who spent more time outdoors. ${ }^{30}$ Similarly, Hsu et al found that in myopic children more outdoor time was not associated with slower myopia progression. ${ }^{29}$ 
In contrast, the most recent randomized controlled intervention studies by $\mathrm{Wu}$ et al showed a slower myopic shift in the intervention group which was encouraged to spend their recess outside the classroom (OR $=0.46(95 \%$ CI, 0.28-0.77; $\mathrm{p}=0.003)) .{ }^{24}$ However, in the same study incidence of myopia showed no significant association with the intervention $(\mathrm{OR}=0.65$ (95\% CI $0.42-1.01))$.

\section{Discussion}

Overall, there is a continuously growing interest in the topic and new studies about the impact of outdoor exposure on myopia development will continue to be published. For example, a very recently cohort study by Singh et al that showed an inverse association of myopia prevalence and outdoor exposure in India. ${ }^{35}$ According to the new evidence, the association between increased time outdoors exposed to natural light and myopia remains in agreement with previous and newer overviews. ${ }^{3,36}$ In this review a relevant number of more recent studies have been included compared to work by Xiong et al and Sherwin et al. ${ }^{3,18}$ It is especially important to note that in contrast to the latest reviews, which only considered randomized controlled trials, ${ }^{36}$ this review includes a large number of prospective cohort studies. Despite having more evidence on the link between increased time outdoors and a lower myopia incidence/prevalence and a later age of myopia onset respectively, some results are still disparate and remain to be looked at critically. Especially, the question whether increased time outdoors can also slow down myopia progression seems to remain debatable.

According to the review of Xiong et al outdoor time has a greater effect on non-myopic than myopic children, more specifically that myopia incidence is observed to be reduced (fit of reported dose-response analysis of subgroup analysis of five studies was $\mathrm{R}^{2}=0.586$ ), but myopia progression cannot be slowed down with more outdoor time $\left(\mathrm{R}^{2}=0.0006\right) .{ }^{3}$ Two of the four prospective studies in this review on myopia progression agreed with this observation, ie, they did not find any association. ${ }^{29,30}$ However, these two studies are known for certain biases. In the first study the authors described a report bias: children with fast annual myopia progression were more myopic at baseline and had a shorter reading distance. ${ }^{29}$ The second study, by Jones-Jordan et al, was considered in the review by Xiong et al and represents data of children who were relatively older with an average age of myopia onset of 10.4 years. $^{30}$
The three intervention trials ${ }^{22-24}$ included in this review were also selected in the newest overview by Cao et al who deduces a slowing down of axial length growth with increased outdoor time. ${ }^{36}$ Jin et al even described changes in axial length as significantly lower in the intervention group, even though the interventional group had more myopic parents, and higher parental education. ${ }^{23}$ Interestingly, $\mathrm{Wu}$ et al observed a slower progression but not a significant association with myopia incidence in their latest randomized controlled intervention study. ${ }^{24}$ Saxena et al found slower progression in the group with higher outdoor activity and $\mathrm{Wu}$ et al described a lower risk of rapid myopia progression. ${ }^{32,33}$ In summary, all of these results give reason to conclude outdoor time may have an protective influence in the progression of myopia.

Looking at the different study types, and beginning with the two cross-sectional studies included in this review. ${ }^{25,26}$ Both studies confirmed an inverse association of time spent outdoors and myopia onset. Results were based on questionnaires. Although both studies are of high quality, it is understood that based on their "snapshot" like design no statement about temporality or any kind of doseresponse relationship can be made.

The prospective cohort studies, which reflect the majority of the more recent publications on this topic, show more consistent results for incidence myopia and myopia progression separately. Most studies indicated a later onset of myopia. A final assessment of the effect of outdoor time on progression cannot be made due to the small number of studies that have actually dealt with the effect of increased outdoor time on myopia progression. Although with this type of study design more information about exposure and outcome sequence is achievable, a large amount of uncertainty remains. First of all, in the presented research, exposure (time outdoors) was only obtained through questionnaires and therefore a recall bias could be present. Second of all, in most of the studies the survey was performed only once. Thirdly, a critical view needs to be taken on how average weekly outdoor time was extrapolated from the questionnaires. Two-thirds of all the included studies assessed number of hours per day, whereas one-third of the studies used number of weekly outdoor exposure hours for the estimation of association. This could result in a bias, because an additional assumption is made that daily time outdoors multiplied by seven can be compared to estimated hours per week. Furthermore, in some studies the differences between 
average time exposed to natural light outdoors in myopic and non-myopic was very small.

Another important limitation concerning the estimate of association, present in four of seven prospective cohort studies and in two of the controlled trials, is the relatively short observation time of one year. Myopia usually develops over several years, making a follow-up period of one year insufficient. ${ }^{16,17,37}$ Also not to be forgotten are confounding factors, for which adjustments were made to different extents in the respective studies. An important example to be mentioned is near-work which is also reported to have an impact on myopia development. Some of the included studies took this in consideration, ${ }^{26,33}$ while others did not.

Taking a closer look at the last category of controlled interventional trials, it is important to note that there are only a handful of such studies available up until now, and many of the above-mentioned confounding and biasing factors apply. In addition, all three studies have their own limitations, which need to be highlighted individually. He et al randomly selected and allocated schools but they did not mask examiners to the randomization. ${ }^{22}$ This could have led to detection bias. Additionally, the proportion of parents with myopia was lower in the intervention group, which could have caused a misclassification bias. In the study by Jin et al a selection bias might be present, since selection of participants was not randomized. ${ }^{23}$ The third and most recent randomized controlled intervention study conducted by Wu et al has been discussed repeatedly: ${ }^{24}$ (1) the withdrawal of a large part of the randomly selected schools shortly before the beginning of the study, as well as (2) concurrent national wide myopia prevention programs in schools and the (3) subjectively estimated time spent outdoors have been commented also by Morgan et al. ${ }^{38}$

This review summarizes some of the most recent and important observational and interventional studies on the topic of outdoor time and myopia. It highlights the heterogeneity of the research on the topic and shows how some factors need to be considered for a critical review analysis.

Because of the incomparability of the included studies, a pooled effect estimate was not calculated. The included studies were not easy to compare mainly because of their different designs. Even though an emphasis was made on the largest published studies, there are still major differences in the study population size, as well as in the age of the study participants. Furthermore, there is an important geographical component. Although most studies were conducted in Asian countries, they were still difficult to compare to one another because of other disparate factors. Some of the prospective studies only dealt with progression, while others only made statements about myopia incidence. More specifically, various thresholds regarding the outdoor time were used, which is why a clear recommendation for a daily outdoor time requirement seems difficult. As pointed out previously, other factors that make it difficult to compare the studies are the different definitions and methods of establishment of outdoor exposure, as well as possible confounders, which were considered to different degrees in the respective studies.

This introduces the several limitations of this review itself: Firstly, selection of the articles was based on the predefined inclusion criteria. It cannot be excluded that hereby a selection bias was caused. Particularly the criterion of language and sample size reduced the number of initially identified articles considerably. Simultaneously, the selection process also increased the homogeneity of the potpourri of articles. A publication bias might be present as well, because non-statistically significant results of unpublished research may have been of relevance. Likewise, there seems to be an overrepresentation of results from certain study populations with multiple articles published.

\section{Conclusion}

In conclusion prevalence and progression of myopia seems to be associated with the modulation of outdoor time. There is growing evidence for a link between increased time outdoors and a lower myopia incidence/prevalence and a later age of myopia onset. In contrast to previous reviews, recent data also suggest that increased time outdoors can slow down myopia progression. The findings of this review indicate that further research is required to better define the association and, ideally, to identify causality. An outstanding emphasis lies on the importance of measurement and quantification of exposure and outcome. Various possibilities for quantifying outdoor time are being developed. ${ }^{39}$ With these new methods and careful study designs more evidence on underlying mechanisms in the development of myopia should be within reach.

\section{Acknowledgments}

The authors initiated this work as part of the ETH Zurich course 701-1701-00L "Human Health, Nutrition, and Environment: Term Paper" during the autumn semester 2018. Furthermore they thank Dr Tim Julian and 
Dr Jeannette Nuessli Guth for their feedback. This work has been presented by Leila Eppenberger at the 17th International Myopia Conference in Tokyo, Japan.

\section{Disclosure}

The authors do not have any proprietary interests or conflicts of interest related to this submission. There was no financial support received for this study.

\section{References}

1. Holden BA, Fricke TR, Wilson DA, et al. Global prevalence of myopia and high myopia and temporal trends from 2000 through 2050. Ophthalmology. 2016;123(5):1036-1042. doi:10.1016/j.ophtha. 2016.01.006

2. World Health Organization. Myopia and high myopia. WHO; 2017. Available from: https://www.who.int/blindness/causes/ MyopiaReportforWeb.pdf?ua=1\&ua=1. Accessed February 9, 2019.

3. Xiong S, Sankaridurg P, Naduvilath T, et al. Time spent in outdoor activities in relation to myopia prevention and control: a meta-analysis and systematic review. Acta Ophthalmol (Copenh). 2017;95(6):551-566. doi:10.1111/aos.13403

4. Hashemi H, Fotouhi A, Yekta A, Pakzad R, Ostadimoghaddam H, Khabazkhoob M. Global and regional estimates of prevalence of refractive errors: systematic review and meta-analysis. $J$ Curr Ophthalmol. 2018;30(1):3-22. doi:10.1016/j.joco.2017.08.009

5. Theophanous C, Modjtahedi BS, Batech M, Marlin DS, Luong TQ, Fong DS. Myopia prevalence and risk factors in children. Clin Ophthalmol Auckl NZ. 2018;12:1581-1587. doi:10.2147/OPTH. S164641

6. Galvis V, Tello A, Otero J, et al. Prevalence of refractive errors in Colombia: MIOPUR study. $\mathrm{Br} \quad J$ Ophthalmol. 2018;102 (10):1320-1323. doi:10.1136/bjophthalmol-2018-312149

7. Flitcroft DI. Emmetropisation and the aetiology of refractive errors. Eye Lond Engl. 2014;28(2):169-179. doi:10.1038/eye.2013.276

8. Lagrèze WA, Joachimsen L, Schaeffel F. [Current recommendations for deceleration of myopia progression]. Ophthalmol Z Dtsch Ophthalmol Ges. 2017;114(1):24-29. German. doi:10.1007/s00347-016-0346-1

9. Rose KA, French AN, Morgan IG. Environmental factors and myopia: paradoxes and prospects for prevention. Asia-Pac J Ophthalmol Phila Pa. 2016;5(6):403-410. doi:10.1097/APO.0000000000000233

10. Galvis V, Tello A, Camacho PA, Parra MM, Merayo-Lloves J. Los factores bioambientales asociados a la miopía: una revisión actualizada. Arch Soc Esp Oftalmol. 2017;92(7):307-325. doi:10.1016/j. oftal.2016.11.016

11. Ramamurthy D, Lin Chua SY, Saw S-M. A review of environmental risk factors for myopia during early life, childhood and adolescence Clin Exp Optom. 2015;98(6):497-506. doi:10.1111/cxo.12346

12. Chuang AY-C. How to effectively manage myopia. Taiwan J Ophthalmol. 2017;7(1):44-47. doi:10.4103/tjo.tjo_24_17

13. Huang J, Wen D, Wang Q, et al. Efficacy comparison of 16 interventions for myopia control in children: a network meta-analysis. Ophthalmology. 2016;123(4):697-708. doi:10.1016/j.ophtha.2015. 11.010

14. Morgan IG, Rose KA. Myopia: is the nature-nurture debate finally over? Clin Exp Optom. 2019;102(1):3-17. doi:10.1111/cxo.12845

15. Ngo C, Saw S-M, Dharani R, Flitcroft I. Does sunlight (bright lights) explain the protective effects of outdoor activity against myopia? Ophthalmic Physiol Opt J Br Coll Ophthalmic Opt Optom. 2013;33 (3):368-372. doi:10.1111/opo.12051

16. Sankaridurg PR, Holden BA. Practical applications to modify and control the development of ametropia. Eye Lond Engl. 2014;28 (2):134-141. doi:10.1038/eye.2013.255
17. Schaeffel F. [Biological mechanisms of myopia]. Ophthalmol Z Dtsch Ophthalmol Ges. 2017;114(1):5-19. German. doi:10.1007/s00347-0160388-4

18. Sherwin JC, Reacher MH, Keogh RH, Khawaja AP, Mackey DA, Foster PJ. The association between time spent outdoors and myopia in children and adolescents: a systematic review and meta-analysis. Ophthalmology. 2012;119(10):2141-2151. doi:10.1016/j.ophtha.2012. 04.020

19. Walline JJ, Lindsley K, Vedula SS, Cotter SA, Mutti DO, Twelker JD. Interventions to slow progression of myopia in children. Cochrane Database Syst Rev. 2011;12:CD004916. doi:10.1002/14651858.CD004916.pub3

20. Zotero. Your personal research assistant. Available from: https:// www.zotero.org/. Accessed January 22, 2019.

21. Beller EM, Glasziou PP, Altman DG, et al. PRISMA for abstracts: reporting systematic reviews in journal and conference abstracts. PLoS Med. 2013;10(4):e1001419. doi:10.1371/journal.pmed.1001419

22. He M, Xiang F, Zeng Y, et al. Effect of time spent outdoors at school on the development of myopia among children in China: a randomized clinical trial. JAMA. 2015;314(11):1142-1148. doi:10. 1001/jama.2015.10803

23. Jin J-X, Hua W-J, Jiang X, et al. Effect of outdoor activity on myopia onset and progression in school-aged children in northeast China: the Sujiatun eye care study. BMC Ophthalmol. 2015;15:73. doi:10.1186/ s12886-015-0052-9

24. Wu P-C, Chen C-T, Lin -K-K, et al. Myopia prevention and outdoor light intensity in a school-based cluster randomized trial. Ophthalmology. 2018;125(8):1239-1250. doi:10.1016/j.ophtha.2017. 12.011

25. Dirani M, Tong L, Gazzard G, et al. Outdoor activity and myopia in Singapore teenage children. Br J Ophthalmol. 2009;93(8):997-1000. doi:10.1136/bjo.2008.150979

26. Sun JT, An M, Yan XB, Li GH, Wang DB. Prevalence and related factors for myopia in school-aged children in Qingdao. J Ophthalmol. 2018;2018:9781987. doi:10.1155/2018/9781987

27. Chen Y, Chang BHW, Ding X, He M. Patterns in longitudinal growth of refraction in Southern Chinese children: cluster and principal component analysis. Sci Rep. 2016;6:37636. doi:10.1038/ srep37636

28. Guggenheim JA, Northstone K, McMahon G, et al. Time outdoors and physical activity as predictors of incident myopia in childhood: a prospective cohort study. Invest Ophthalmol Vis Sci. 2012;53 (6):2856-2865. doi:10.1167/iovs.11-9091

29. Hsu -C-C, Huang N, Lin P-Y, et al. Risk factors for myopia progression in second-grade primary school children in Taipei: a population-based cohort study. Br J Ophthalmol. 2017;101(12):1611-1617. doi:10.1136/ bjophthalmol-2016-309299

30. Jones-Jordan LA, Sinnott LT, Cotter SA, et al. Time outdoors, visual activity, and myopia progression in juvenile-onset myopes. Invest Ophthalmol Vis Sci. 2012;53(11):7169-7175. doi:10.1167/iovs.118336

31. Ma Y, Lin S, Zhu J, et al. Different patterns of myopia prevalence and progression between internal migrant and local resident school children in Shanghai, China: a 2-year cohort study. BMC Ophthalmol. 2018;18(1):53. doi:10.1186/s12886-018-0716-3

32. Saxena R, Vashist P, Tandon R, et al. Incidence and progression of myopia and associated factors in urban school children in Delhi: the North India Myopia Study (NIM Study). PLoS One. 2017;12(12): e0189774. doi:10.1371/journal.pone.0189774

33. Wu L-J, Wang Y-X, You Q-S, et al. Risk factors of myopic shift among primary school children in Beijing, China: a prospective study. Int J Med Sci. 2015;12(8):633-638. doi:10.7150/ijms.12133

34. Saxena R, Vashist P, Tandon R, et al. Prevalence of myopia and its risk factors in urban school children in Delhi: the North India Myopia Study (NIM Study). PLoS One. 2015;10(2):e0117349. doi:10.1371/ journal.pone. 0117349 
35. Singh NK, James RM, Yadav A, Kumar R, Asthana S, Labani S. Prevalence of myopia and associated risk factors in schoolchildren in North India. Optom Vis Sci. 2019;96(3):200-205. doi:10.1097/ OPX.0000000000001344

36. Cao K, Wan Y, Yusufu M, Wang N. Significance of outdoor time for myopia prevention: a systematic review and meta-analysis based on randomized controlled trials. Ophthalmic Res. 2020;63(2):97-105. doi:10.1159/000501937
37. Morgan IG, Ohno-Matsui K, Saw S-M. Myopia. Lancet Lond Engl. 2012;379(9827):1739-1748. doi:10.1016/S0140-6736(12)60272-4

38. Morgan IG. Myopia prevention and outdoor light intensity in a school-based cluster randomized trial. Ophthalmology. 2018;125 (8):1251-1252. doi:10.1016/j.ophtha.2018.04.016

39. Wang J, He X-G, Xu X. The measurement of time spent outdoors in child myopia research: a systematic review. Int $J$ Ophthalmol. 2018;11(6):1045-1052. doi:10.18240/ijo.2018.06.24
Clinical Ophthalmology

\section{Publish your work in this journal}

Clinical Ophthalmology is an international, peer-reviewed journal covering all subspecialties within ophthalmology. Key topics include: Optometry; Visual science; Pharmacology and drug therapy in eye diseases; Basic Sciences; Primary and Secondary eye care; Patient Safety and Quality of Care Improvements. This journal is indexed on PubMed

Submit your manuscript here: https://www.dovepress.com/clinical-ophthalmology-journal

\section{Dovepress}

Central and CAS, and is the official journal of The Society of Clinical Ophthalmology (SCO). The manuscript management system is completely online and includes a very quick and fair peer-review system, which is all easy to use. Visit http://www.dovepress.com/ testimonials.php to read real quotes from published authors. 